Paulasto, H. \& S. Pöyhönen (toim.) 2020. Kieli ja taide - soveltavan kielentutkimuksen ja taiteen risteämiä. Language and the arts - creative inquiry in applied linguistics. AFinLA-e. Soveltavan kielitieteen tutkimuksia n:o 74. 84-107.

\author{
Mervi Kastari \\ Jyväskylän yliopisto
}

\title{
S2-lukija tulkitsijana selkomukautetun kaunokirjallisuuden lukupiirissä
}

This article discusses reading circles of adult Finnish as a second language (L2) readers. The books that were read and discussed in the circles were easy-to-read fiction. The study focuses on how the readers interpret what they read and what kind of support they need for their interpretations. The analysis utilizes the concept of scaffolding, used in socio-cultural learning theory. The readers' reading stances vary from what is literally said in the text to creating their own interpretations of the hidden meanings of the text. The latter are not very common in the reading circles, although many participants express a wish to create and discuss interpretations too. The analysis shows that interpretations can emerge if the participants are scaffolded in the reading circle by the teacher and other readers. The study thus provides useful information for designing reading circles in adult language education.

Keywords: L2 reading, easy-to-read literature, interpretation, reading-circles Asiasanat: lukeminen toisella kielellä, selkomukautettu kaunokirjallisuus, tulkinta, lukupiirit 


\section{Johdanto}

Kaunokirjallisuus ja lukupiirit ovat osa aikuisten maahanmuuttajien suomen kielen opetusta. Opettajat ja koulutuksenjärjestäjät näkevät niissä mahdollisuuden tukea kielenoppimista ja hyödyntävät kirjallisuutta ja lukupiirejä osana työtään. Tässä artikkelissa keskityn tarkastelemaan toisella kielellään lukevien henkilöiden tulkintaa selkomukautetusta kaunokirjallisuudesta. Aineisto on kerätty kotoutumiskoulutuksen lukupiireistä. Artikkeli on osa soveltavan kielitieteen väitöskirjatutkimustani, joka käsittelee selkomukautettua kaunokirjallisuutta S2- eli suomi toisena kielenä -kontekstissa. Olen aiemmin tarkastellut aihetta kielenoppimisen näkökulmasta, ja rajaan kielenoppimisen tässä artikkelini ulkopuolelle joitain pieniä huomioita lukuun ottamatta.

Artikkelini tutkimuskysymykset ovat, miten aikuinen S2-lukija muodostaa tulkintaa ja tulkitsee selkomukautettua romaania, millaisia haasteita hän siinä kohtaa ja millaista tukea hän tarvitsee. Tällaista tietoa on toistaiseksi melko vähän. Aiemmassa S2-tutkimuksessa keskeisin on Vaaralan (2009) novellien lukemista koskeva tutkimus. S2-lukijoiden tulkintoja selkokirjallisuudesta on niin ikään tutkittu hyvin vähän. Artikkelin tarkoituksena on tuottaa tietoa S2-lukijoiden lukupiirien kehittämiseen.

Artikkeli rakentuu siten, että luvussa 2 kartoitan tutkimuksen keskeisimpiä viitekehyksiä ja käsitteitä, kuten selkomukautettua kaunokirjallisuutta sekä tuen (sosiokulttuurinen scaffolding) ja tulkinnan käsitteitä. Lisäksi kuvaan tutkimuksen aineiston ja menetelmät. Luvussa 3 tarkastelen lukupiiriä ja selkoteoksia tuen muotoina, lukupiirin kirjoja koskevia kysymyksiä lukijan tukena sekä itse tulkinnan muodostamista ja sen haasteita ja tukemista. Luku 4 muodostaa yhteenvedon esitetystä.

\section{Tutkimuksen taustaa ja käsitteitä}

\subsection{Selkomukautettu kaunokirjallisuus}

Selkomukautettu kaunokirjallisuus on tuotettu siten, että alkuperäinen yleiskielinen teos on mukautettu sisällöltään, sanastoltaan ja rakenteeltaan ymmärrettävämmäksi ja luettavammaksi (Leskelä 2019: 95). Suomalaisten selkomukautettujen teosten kieli on pääosin vaativan tason selkokieltä, joka lähestyy yleiskieltä. Tällöin sanasto, rakenteet ja sisällöt ovat monimuotoisia ja antavat lukijalle mahdollisuuden kohdata vaikeampia ja mutkikkaampia kielellisiä rakenteita. (Leskelä 2019:170-171, 274.) Laajimmin tutkittuja kaunokirjallisia selkomukautuksia ovat englanninkieliset graded readers -teokset, jotka on suunnattu kielenoppijoille. Sheehan (2015: 294) katsoo, että graded readers -teosten lukeminen tuo kielenoppijalle kielellistä tukea helpotetulla kielellään, mutta tarjoaa silti haastavaa sisältöä. Liian vaikea kieli 
edellyttää toisella kielellä lukevalta dekoodaavaa lukutapaa, mikä ei mahdollista sujuvaa lukemista ja on hyvin epämotivoivaa lukijalle. Tällainen lukeminen vaatii kovaa ponnistelua, jatkuvaa sanojen kääntämistä ja tuntemattomien kieliopillisten konstruktioiden selvittämistä, joten on epätodennäköistä saavuttaa lukunautinto. (Claridge 2011:23, 190.) Sheehan (2015: 303-304, 307) toteaakin, että helpotettu kieli auttaa kielenoppijoita pääsemään osallisiksi sisällöistä, jotka olisivat heidän ulottumattomissaan alkuperäisessä kieliasussaan.

Sheehan (2015: 303-304) arvioi, että kielellisesti yksinkertaistetut ja lyhennetyt teokset eivät varmastikaan tuo lukijan ulottuville kaikkia mahdollisia lukukokemuksia ja koko alkuperäistä teosta, mutta kyseessä onkin kompromissi, joka mahdollistaa kaunokirjallisuuden lukemisen ylipäätään. Lisäksi on huomioitava ensimmäisen kielen (jatkossa L1) ja toisen kielen (L2) lukijan todennäköinen näkökulma- ja kokemuksellinen ero. Claridge (2011: 3, 48, 49) katsoo, että graded readers -teoksia on kritisoitu joissain tutkimuksissa muun muassa siksi, että niiden lukukokemusta ei ole irrotettu tutkijan omasta, L1-lukijan näkökulmasta. Toisaalta on kysytty varsin vähän, miten L2-lukija kokee niiden lukemisen. Myös S2-lukijan kokemus selkoteoksesta on todennäköisesti erilainen kuin S1-lukijan (ks. L1- ja L2-lukemisen eroista Vaarala 2009: 150-258), ja tämä on tärkeää muistaa esimerkiksi selkomukautetun romaanin tulkinnallisuutta tai muita taiteellisia ominaisuuksia pohdittaessa. Day ja Bamford (1998: 64) tuovat vertailukohdaksi muut eri lukijaryhmille suunnatut kirjallisuuden lajit, kuten lasten- tai nuortenkirjallisuuden, joita nykyisin pidetään omina kirjallisuuden tyyppeinään. Ne tuskin yltäisivät tähän asemaan, jos niitä tarkasteltaisiin esimerkiksi vain aikuisen lukijan näkökulmasta. Selkomukautus ei ole välttämättä sama teos kuin yleiskielinen alkuperäisteos, mutta se voi olla kehittyvällä toisella kielellään lukevan näkökulmasta mielekäs kaunokirjallinen lukukokemus.

\subsection{Kaunokirjallisuuden tulkinta}

Kaunokirjallinen tulkinta on yksinkertaistaen sen määrittämistä, mistä tekstissä on lukijan mielestä kyse (Culler 1997: 64). Yhden S2-lukijan mielestä kirja henkilö voi esimerkiksi olla sairas mutta toisen mielestä vain esittää sairasta. Nämä ovat kaksi erilaista tulkintaa kirjan sisällöistä. Tulkitseminen onkin aina luonteeltaan spekulatiivista (Culler 1997: 64). Rosenblattin (1986: 123) mukaan tekstin merkitykset eivät ole itse tekstissä eivätkä lukijan mielessä vaan ne muodostuvat transaktiossa, lukijan ja tekstin vuorovaikutuksessa.

Tulkinnan muodostamisen lähtökohtana ovat havainto ja ymmärrys. Teksteistä havaitaan yksilöllisesti eri asioita, sillä havainto riippuu yksilöllisistä skeemoista, joita käytetään tulkintatoiminnassa, ja lukija myös suhteuttaa havaintonsa johonkin itselleen tuttuun (Weber 
1996: 234). Yhtä lailla myös tekstin ymmärtäminen on välttämätöntä (Davis 1992: 359). Lukeminen on tulkitsevaa toimintaa juuri ymmärryksen näkökulmasta: se on kasvavan ymmärryksen kokemusta, joka muuttuu ajan myötä (Langer 1990: 231, 232, 248). Nämä tulkinnan muodostamisen lähtökohdat muotoutuvat eri lukijoille yksilöllisesti erilaisiksi. Silti tekstiä ei voi panna tarkoittamaan mitä vain, ja lukijan on ainakin periaatteen tasolla pystyttävä vakuuttamaan myös muut tulkintansa asianmukaisuudesta (Culler 1997: 65-66).

Yksilöllisten tekijöiden lisäksi tulkintaan voivat vaikuttaa monenlaiset kontekstit, kuten luetusta keskustelu (Vaarala 2009: 14, 16). Lukupiireille on luonteenomaista, että lukeminen ja tulkinnoista keskustelu yhdistyvät (Kusanagi 2015: 236). Tulkinta on usein suuresti sosiaalista (Culler 1997: 64) ja dynaamista. Vaarala (2009: 211) korostaa lukemisen prosessiluonnetta, jossa tulkinnat voivat muuttua eri lukukertojen välillä ja ryhmäkeskustelujen myötä. Hänen mukaansa kirjallisuus merkityksineen ja tulkintoineen syntyykin L2-oppijoiden vuorovaikutuksessa tekstin ympärillä (2009: 75). Tulkinta on siis toimintana prosessimaista, ja prosessiin vaikuttavat sisäiset ja ulkoiset kontekstit. Tulkinnan muodostamista ja itse tulkintaa ei näin ole helppoa erottaa toisistaan. Culler $(1997: 63,65)$ katsookin, että tulkinta on aina kertomus lukemisesta, siitä miten tulkintaan on päästy ja millä perusteella.

\subsection{Tulkinnan tuki}

Lukupiirit tarjoavat tukea toisella kielellä lukemiseen ja kaunokirjallisen tulkinnan muodostamiseen. Tämä tuki, scaffolding, on sosiokulttuurisen oppimisen teorian käsite. Teoria on saanut alkunsa Vygotskylta (1978), mutta termi scaffolding ei ollut alunalkujaan Vygotskyn käyttämä vaan se on luotu myöhemmin (Swain ym. 2015: 25). Scaffolding merkitsee tuettua suoriutumista (Ohta 2000: 86). Siinä ei ainoastaan auteta oppijaa tekemään jotain, vaan johdatetaan hänet tietoon siitä, miten jotain tehdään (Gibbons 2003: 249). Scaffolding on joskus suomennettu rakennustelineopetukseksi (Lehtonen 2015: 29). Swain ym. (2015: xvii-xviii) ovat huomanneet, että scaffolding-termiä sovelletaan toisinaan mekanistisesti, mitä he pitävät Vygotskyn teorian tarkoituksen vastaisena.

Käytän scaffolding-käsitteestä tässä artikkelissa nimitystä tuki ja tukeminen. Vastaavaan nimitysvalintaan on päätynyt Suni (2008: 118). Kyseessä ei ole ainoastaan pedagoginen menetelmä vaan tuki on laajempi ja myös yhteisöllinen ilmiö. Lukupiirissä tuki ilmenee monimuotoisena. Se on esimerkiksi tukeutumista keskustelukumppaniin tai kirjaan, tai se voi sisältyä opettajan ja osallistujien vuorovaikutukseen tai osallistujien vertaisvuorovaikutukseen (ks. Swain ym. 2015: 25; Suni 2008: 79, 117-118). Opettaja voi tukea tulkinnan muodostamista omalla toiminnallaan. Tutkimissani lukupiireissä käytettiin esimerkiksi kirjaa koskevia kysymyksiä, jotka toimivat keskustelun tukena. Palaan tähän luvussa 3. 


\subsection{Aineisto ja analyysi}

Artikkelin aineisto on koottu lukupiireistä, jotka toimivat kahdessa sisäsuomalaisessa oppilaitoksessa, yhdessä kokeiluna ja toisessa vakituisesti. Lukupiirit toimivat osana kotoutumiskoulutusta, mutta olivat opiskelijoille vapaaehtoista toimintaa. Lukupiirejä oli kolme, ja ne kokoontuivat vuosina 2016 ja 2017. Käytän analyysissä hyväkseni etnografisen tutkimuksen tapaa kuvata tutkimuskohdetta tulkitsevan analyysin avulla (ks. Brewer 2000: 105-106). Etnografia on menetelmä, jolla tutkitaan sosiaalisia tilanteita olemalla niissä mukana ja havainnoimalla niitä (Emerson ym. 2011: 34).

Lukupiireillä oli eri opettajia ja yhden lukupiirin vetäjäksi tarjouduin itse. En ollut sitä vetäessäni vielä osallistunut muihin lukupiireihin. Tämän oman lukupiirini osalta tutkimusasetelma on retrospektiivinen, sillä vedin lukupiiriä ensin ja sen päätyttyä palasin tutkimusta varten kokoamani aineiston pariin tutkijana. Tässä mielessä tutkimuksessani on osin myös autoetnografisen asetelman piirteitä, sillä olin näin myös kentän toimija enkä vain havainnoitsija (ks. Nissi 2014: 336). Se, että olin yhden lukupiirin opettaja-osallistuja, tuottaa minulle yhden elämysmaailman lisää tutkimukseni kenttätyöstä. Tämä laajentaa etnografista kompetenssiani kentän suhteen, koska olen ollut lukupiireissä sekä sisä- että ulkopuolinen. (Ks. Marttila 2014: 376-377.) Tutkimuseettiseltä kannalta se kuitenkin samalla edellyttää tietoista etäännytystä, toiseuden ja tutkijuuden rakentamista suhteessa kenttään (Nissi 2014: 354). Lukupiirissäni toimin opettajana, ja tutkijana toimin, kun palasin myöhemmin aineiston pariin. Tämän artikkelin tutkimuskysymykset muotoutuivat tutkijan roolissa kenttätyövaiheiden lopulla ja oman lukupiirini jo päätyttyä. Autoetnografiasta poiketen itsehavainnointi ei ole ensisijainen tiedonhankinnan keinoni, ja fokus on S2-lukijoissa.

Tutkimus valmisteltiin selvittämällä huolellisesti tutkimuseettiset näkökohdat kuten tutkimusluvat ja osallistujien informointi. Ennen lukupiirien alkua kävin oppilaitoksissa esittelemässä tutkimustani niissä ryhmissä, joista oli mahdollista osallistua lukupiireihin. Esittelyn jälkeen harkinta-aikaa tutkimuksen osallistumiseen oli 1-2 viikkoa. Osallistujilla oli tiedossaan myös, että mikäli he eivät halua oman lukupiirinsä olevan mukana tutkimuksessa, minä voin tarvittaessa mennä johonkin toiseen lukupiiriin ja että tällaisen toiveen voi kertoa omalle opettajalle. Harkinta-ajan jälkeen järjestettiin tilaisuus, jossa selvitettiin tutkimusluvan sisältö ennen allekirjoittamista. Pyysin luvat myös opettajilta. Minulla oli suostumuslomakkeiden liitteeksi suomenkielinen selkomukautus ja englanninkielinen käännös. Käytin sekä esittelytilaisuudessa että tutkimuslupien läpikäynnissä Papunetin (Papunetin kuvapankki) havainnollistavia kuvia kertoessani esimerkiksi tallennuksesta ja kerroin asiat myös englanniksi. Osallistujilta pyydettiin kirjallinen suostumus vapaavalintaiseen haastatteluun, 
haastattelujen ja lukupiiritapaamisten video- ja äänitallentamiseen sekä tallenteiden käyttöön tutkimustarkoituksessa. Samoin selostettiin, että kerätty materiaali säilytetään siten, ettei ulkopuolisilla ole siihen pääsyä.

Lukupiirit kokoontuivat kerran viikossa 10-13 kertaa noin 3 kuukauden ajan ja ne kaikki olivat ohjattuja lukupiirejä. Lukupiireissä toimittiin samojen periaatteiden mukaan, vaikka opettajat eivät olleet yhteistyössä keskenään. Kussakin lukupiirissä luettiin yksi kirja. Kaikkien lukupiiritapaamisten perusrakenteeseen kuului, että joka kerraksi luettiin ennalta kirjasta 1-2 lukua, ja aluksi käytiin läpi opettajan tuomia valmiita sisältökysymyksiä pareina tai pienryhminä. Tämän jälkeen keskusteltiin vielä koko lukupiirin kesken opettajan johdolla.

Lukupiirien teokset olivat (1) Leena Lehtolaisen (2012) Ensimmäinen murhani, (2) Henning Mankellin (2005) Valokuvaajan kuolema ja (3) Sisko Istanmäen (2006) Liian paksu perhoseksi. Viittaan jatkossa teoksiin suluissa mainituilla numerotunnisteilla. Teokset 1 ja 2 ovat dekkareita, joissa molemmissa päähenkilönä oleva poliisi selvittää murhaa. Teos 3 taas on 1960-luvun maaseudulle sijoittuva kertomus ison naisen ja pienen miehen parisuhteesta. Kaikki teokset sisältävät niin pää- kuin sivuhenkilöiden elämäntilanteita, iloja ja suruja sekä inmissuhteita.

Aineistoni koostuu lukupiirien video- ja äänitallenteista, joita on noin 10 tuntia, sekä haastatteluista ( $n=24)$. Tallenteita on kaikista lukupiireistä. Lisäksi minulla on kenttämuistiinpanoja tilanteista. Olen poiminut aineistosta jaksoja, jotka sisältävät tulkitsevaa keskustelua tai muulla tavoin tuovat vastauksia tässä artikkelissa asettamiini tutkimuskysymyksiin. Haastatteluista taas käytän osan, joka täydentää vastauksia tutkimuskysymyksiin, esimerkiksi haastattelukysymykset toiveista lukupiiriä kohtaan. Valitsemani jaksot olen litteroinut alkuperäiskielet säilyttäen. Käyttämäni litteraatio on ns. karkeaa litteraatiota, jossa henkilön puhe on merkitty sanatarkasti, mutta ilman täsmällisempiä, esimerkiksi keskustelunanalyysissä käytettyjä litterointimerkkejä, koska aineistoa tarkastellaan asiasisältöjen tasolla (ks. Yhteiskuntatieteellinen tietoarkisto 2017).

Haastattelin analyysiani varten kahdeksaa henkilöä (yht. 24) kustakin lukupiiristä. Haastateltavilta henkilöiltä kerättiin haastattelun yhteydessä taustatietoja. Nämä lukupiiriläiset olivat 20-50 vuoden ikäisiä, ja he olivat olleet Suomessa seitsemästä kuukaudesta 3,5 vuoteen. Heistä 16:lla oli korkeakoulutus tai korkeakouluopintoja. Neljällä oli ammattikoulutus, yhdellä lukiokoulutus ja kahdella peruskoulutausta. Yhdeltä ei ole koulutustaustatietoa. Osallistujien kielitaito vaihteli arviolta A1.3-tasolta B1-tasolle. Kaikilla ei ollut ajantasaista tietoa kielitaitonsa tasosta, joten tasoarviot perustuvat minun ja osallistujien omaan arvioon. Osallistujat olivat kotoisin Euroopasta (8 osallistujaa), Kaakkois-Aasiasta (6), Lähi-idästä (4), Pohjois-Afrikasta (2), Itä-Aasiasta (1), Länsi-Afrikasta (1), Oseaniasta (1) ja Pohjois-Amerikasta 
(1). Kirjallisuuden lukemista harrasti entuudestaan muilla osaamillaan kielillä 15 haastateltavaa, jotka kertoivat olevansa aktiivisia lukijoita. Sen sijaan 9 haastateltavaa kertoi, ettei pitänyt lukemisesta entuudestaan. Analyysilukujen keskustelu- ja haastattelujaksoissa osallistujien nimet on muutettu.

\section{Kaunokirjallinen tulkinta ja kokemukset lukupiiristä}

Lähden tässä luvussa liikkeelle lukupiirien tarkastelusta aluksi hieman etäämmältä siten, että tarkastelen osallistujien ajatuksia lukupiireistä ja selkoteoksista sekä heidän tavoitteitaan ja motivaatioitaan. Näin tulee näkyviin lukupiirin ja selkoteosten yksilöllisesti vaihteleva merkitys tuen muotoina. Tämän jälkeen näkökulma siirtyy asteittain syvemmälle ensin lukupiirin käytäntöihin ja erityisesti sisältökysymyksiin tuen muotoina sekä osallistujien haluun muodostaa tulkintaa. Sitten siirryn edelleen itse tulkinnan muodostamiseen sekä sen tukemiseen ja haasteisiin.

\subsection{Lukupiiri ja selkoteokset tuen muotoina osallistujien näkökulmasta}

Halu oppia suomea oli tavallisin syy tulla lukupiiriin. Sen mainitsi jossain muodossa jokainen haastateltu lukupiiriläinen, mutta vain kuusi henkilöä mainitsi lisäksi pitävänsä lukemisesta, vaikka 15 haastateltua osallistujaa harrasti jo ennalta kaunokirjallisuutta muilla osaamillaan kielillä. Kuitenkin ne, jotka lukupiiriin jäivät, nauttivat aina myös lukemisesta vähintään jollain lailla, mikä ilmeni haastatteluissa ja aktiivisena toimintana lukupiirissä. Edwin luki kirjan (3) itsenäisesti loppuun työharjoittelussa ja tiivistää esimerkissä 1 lukukokemuksensa:

(1) Edwin: Kirja tuntui ihanalta. ---. ---. [Puhetta oppimiskokemuksista.] Tarinassa ensin he erottuvainen [erosivat], sitten yksin ja sitten yhdessä. Tosi hyvä lopulta. Ei surullinen. Ernin äiti kuollut surullinen juttu, mutta aina kiusaa.

Edwinin kuvaus kirjasta ihanana ei ollut poikkeava vaan kaikkia kolmea selkoteosta kiiteltiin lukukokemuksena. Jotkut mainitsivat myös, ettei selkoteoksen lukeminen ollut kielellisesti aivan helppoa, mutta lukunautinto tai tarinan jännittävyys sai jatkamaan.

Pääosin lukupiireissä viihdyttiin ja kaunokirjallisella nautinnolla oli siinä keskeinen merkitys. Kuitenkin esimerkiksi Danielille lukupiiri oli toisenlainen kokemus. Tullessaan lukupiiriin Daniel oli erittäin motivoitunut:

(2) Mervi: Miksi sä tulit lukupiiriin?

Daniel: Haluan oppia suomia enemmän. Koska mä olen... mmm... Ma olen valmis. I'm ready. I'm ready to go to anywhere I can get Finnish language. 
Mervi: Okei. Vaikka sä sanoit, että tää lukupiiri ei oo ihan niinku... Sä sanoit, että et tykkää kirjoista.

Daniel: It's language. I'm ready.

Esimerkissä 2 Daniel kuvaa, kuinka hän on valmis mihin vain oppiakseen suomea, ja on tullut siksi lukupiiriin, vaikka ei pidä kirjoista. Hänen laillaan myös kaksi muuta haastateltua osallistujaa tuli motivoituneena lukupiiriin, vaikka eivät pitäneet kirjoista. Lopulta he kuitenkin keskeyttivät lukupiirin ja sanoivat, etteivät halua lukea kirjaa.

Yhteensä yhdeksän haastateltua osallistujaa tuli lukupiiriin ilmoittaen, ettei pidä kirjallisuudesta. Heistä kuusi kuitenkin, jopa omaksi yllätyksekseen, piti lukupiirin kirjasta ja osallistui aktiivisesti. Ainakin osa tunsi myös tarvetta tulkitsevaan keskusteluun tai oppi sitä lukupiirissä. Eräs osallistuja esimerkiksi saattoi aluksi lukea vastauksia ääneen suoraan kirjasta, mutta kertoi myöhemmin alkaneensa kaivata kysymyksiä, joihin ei olisi suoraa vastausta. Kolme haastateltua osallistujaa, joukossaan Daniel, kuitenkin suhtautui kirjaan jatkuvasti toisin. He eivät nauttineet kaunokirjallisuuden lukemisesta ja lopulta keskeyttivät lukupiiriin osallistumisensa. Heidän ensisijainen motivaationsa lukupiiriin osallistumisessa oli suomen oppiminen, mutta se ei yksin riittänyt. Lukupiiri on hyvä kielenoppimisen muoto hyvin monille, mutta ei aivan kaikille (Kastari 2019: 360). Esimerkiksi juuri Danielille se ei ollut toimivin keino, ja hän hakeutuikin siitä pois.

Lukunautinnon kokemus oli keskeistä lukupiirissä jatkamisessa ja sitä voidaan myös tukea. Selkokirjallisuudelle on asetettu tavoite tarjota mahdollisuus kielellisiin elämyksiin ja pääsy kirjallisuuden maailmaan (Leskelä, 2019: 71). Graded readers -kirjallisuuden on katsottu tukevan L2-lukijan lukunautintoa mukautetulla sisällöllään ja leksikaalisella ja syntaktisella tasollaan. Kielitaidon tasoon nähden liian vaikea kieli johtaa dekoodaavaan lukutapaan, joka ei mahdollista sujuvaa lukemista. (Claridge 2011: 23, 107, 190.) Tätä kautta selkokieli tukee S2-lukijan kaunokirjallista lukunautintoa ja lukemista. Monet olivat epävarmoja kielitaidostaan eivätkä odottaneet pystyvänsä lukemaan kokonaista kirjaa. Lukupiiri tuki lukemisen aloittamista ja se oli joillekin yksi syy tulla lukupiiriin. Esimerkiksi Pauline kuvaa esimerkissä 3:

(3) Pauline: Minusta oli tosi hyvä, kun minä saan kirjan, meidän [lukupiirin] kirjan koulussa. Sitten minä voin aloittaa. --- otin [lainaksi kirjastosta] ne kirjat [kolme selkokirjaa] ennen lukupiiriä, --- ja minä en voinut aloittaa lukemista. Minä pelkäsin. Mutta kun lukupiiri alkoi, minun täytyi aloittaa lukemista, kun se oli mahdollista.

Joillakin taustalla vaikuttivat myös epäonnistumisen kokemukset yleiskielisen kaunokirjallisuuden parissa. Toisin kuin yleiskieliset teokset romaanien selkomukautukset toivat 
kaunokirjallisuuden heidän ulottuvilleen kielitaidon vaiheen (noin A1.3-B1) estämättä. Haastatteluissa kuvattiin iloa, kun lukeminen onnistui. Eräs hypähteli tuolissaan kuvatessaan haastattelussa onnistumisen tunnettaan kirjan parissa: "Ja minä voin lukea! Minä voin lukea!" Kehittyvästä kielitaidostakin voi nauttia käyttämällä sitä itselle merkitykselliseen toimintaan, kuten tässä kaunokirjalliseen lukemiseen, jonka selkokieli tekee mahdolliseksi.

Muutamat mainitsivat lukupiiriin tulon syyksi halun ymmärtää kirjaa paremmin ja kokivat myös, että lukupiiri auttoi tässä. Esimerkiksi Kylie kertoo seuraavasti:

(4) Mervi: Mitä sä ajattelet kirjojen lukemisesta suomeksi?

Kylie: Ajattelen, että ehkä jos luet yksin, on vähän vaikeaa. Arvostan, että voimme osallistua lukupiirissä.

$---$

Mervi: Lukupiirissä te puhutte siitä kirjasta. Auttaako se sinua jotenkin?

Kylie: Ehkä miten selitämme kirjasta.

Kylie ilmaisee esimerkissä 4 saavansa tukea lukupiiristä, kun kirjan sisältöjä selitettiin. Myös Vaarala (2009: 212-213) ja Kim (2004: 162) ovat havainneet, että ryhmässä toimiminen on L2-lukijalle tärkeää ymmärryksen helpottamiseksi. Vera kuvailee lukupiirin merkitystä lukemiselleen toisesta näkökulmasta:

(5) Vera: ---. ---. Minä en tykkää lukemista, mutta nyt se on mielenkiintoista.

Mervi: Mikä siitä tekee mielenkiintoista?

Vera: Se on rumatyö, mä menee kurssikaverin kanssa.

Mervi: Aa, millainen työ?

Vera: Se on ryma [ryhmä], me lue yhdessä ja keskustelee.

Vera toteaa esimerkissä 5, ettei pitänyt lukemisesta, mutta lukupiirissä siitä tuli kiinnostavaa, koska se oli ryhmätyötä. Tämä lukupiirin yhteisöllinen ulottuvuus sai hänet osallistumaan peräti kahteen lukupiiriin.

\subsection{Lukupiirin kysymykset lukijan tukena ja halu muodostaa tulkinta}

Kaikissa kolmessa lukupiirissä käytettiin keskustelun pohjana opettajien tuomia, valmiita kysymyksiä luetusta. Osa kysymyksistä oli sisällönymmärtämistä kontrolloivia kysymyksiä: "Mitä laatikossa oli?" Vastauksen näihin kysymyksiin saattoi lukea usein suoraan kirjasta. Kysymys oli kuitenkin kirjan juonenkulun ymmärtämisen kannalta olennainen. Toiset taas olivat tulkintakysymyksiä: "Miksi Rouva oli niin ilkeä?" Tähän ei ollut ilmiselvää vastausta kirjassa, vaan vastaaminen vaati tulkinnan muodostamista. 
Nämä kysymykset jakoivat mielipiteitä voimakkaasti. Haastatteluissa erityisesti juuri sisällönymmärtämiskysymyksiä sekä kritisoitiin kovasti että pidettiin ehdottoman tarpeellisina. Yhdessä lukupiirissä kokeiltiin toimintaa ilman kysymyksiä, mutta pian kysymykset otettiin taas käyttöön. Beatrice koki, että ilman kysymyksiä jotain puuttui ja jatkaa:

(6) Beatrice: [Painokkaasti:] We need the questions. Joo, koska se auttaa meitä, jos meillä on kysymyksiä. Koska sinä tarvitsee ajatella ja ymmärtää, mitä tapahtui. Mutta jos se ei ole kysymyksiä, sinä et ymmärtää kaikki ja sinä et ajattele.

Beatrice (tasoarvio A2) toteaa esimerkissä 6, että kysymyksiä tarvitaan, koska muuten S2-lukija ei välttämättä ymmärrä, ettei ymmärrä, ja tässä hän oli samoilla linjoilla muiden kysymyksiä puolustavien kanssa. Jotkut kuvailivat kysymyksiä hyväksi tarkistuslistaksi siitä, onko lukija varmasti havainnut tekstistä juonen kannalta oleellisimman. Kysymyksiä käytettiin myös tekstiin orientoitumiseen. Muutamat, lähinnä B1-tason lukijat taas pitivät kontrollikysymyksiä tylsinä, mutta sietivät niitä, koska muut osallistujat tarvitsivat niitä. Kaksi tällaista henkilöä kuitenkin erosi lukupiiristä. He totesivat, että kysymysten ja niihin vastaamisen lisäksi olisi pitänyt olla muutakin keskustelua, jotta he olisivat voineet jatkaa.

Jotkut toivoivat kysymyksiä, joihin ei olisi suoraa vastausta, muutamat taas abstraktimpia kysymyksiä. Esimerkiksi Uriah toteaa, että konkreettiset kysymykset auttavat ymmärtämään faktat, mutta jatkaa esimerkissä 7:

(7) Uriah: Mä tykkään abstrakti [kysymys]. Ja open [engl. open 'avoin'] vastaus. Abstrakti on hyvä, koska keskustelemme paljon erilaisia mieltä kaverin kanssa ja [esittää keskustelua:] "minä ajattelen tämä vastaus ei ole hyvä, koska..." Nyt minä ajattelen suomeksi. Lukupiiri on hyvä, koska auttaa... koska tarvitsee ajattelee suomeksi.

Uriahin mielestä abstraktit kysymykset avoimine vastauksineen toivat keskustelua eri näkemyksistä teoksesta 1. Joidenkin osallistujien ratkaisu oli yrittää käyttää mahdollisimman vähän kirjaa ja vastata mahdollisimman paljon omin sanoin. Useimmille tämä ei ollut kuitenkaan riittävä kompromissi, koska heidän produktiivinen kielitaitonsa ei vielä mahdollistanut sitä. Myös B1-tasoisten oli välttämätöntä tukeutua itseilmaisussaan kirjan tekstiin. A1.3-tasoiset olivat vahvasti kirjan tekstin varassa keskustelussaan ja he olivat myös paljon kuuntelijan roolissa. L2-lukijat tarvitsevat usein kielellistä tukea (Sheehan 2015: 294; Christie 2019: 118) ja hyödyntävät kysymyksiä luetunymmärtämisen strategisena tukena (Urlaub 2012: 296). Kysymykset näyttäytyivätkin osallistujille tärkeinä juuri tuen näkökulmasta, mutta niihin ei haluttu rajoittua. Christie (2019: 121) jatkaa, että valmiit kysymykset voivat 
auttaa huomaamaan relevantit juonenkäänteet, mutta voivat olla myös pitkäveteisiä. Pakolliset kysymykset voivat jopa vaikuttaa toisella kielellä lukevan lukunautintoon negatiivisesti (Claridge 2011: 48), kuten kaksi lukupiiristä eronnutta kertoi.

Nekin, joille oli vielä haasteellista ottaa kovin aktiivisesti osaa tulkitsevaan keskusteluun, toivoivat sitä kysymyksiin vastaamisen lisäksi. He kokivat ymmärtämistä kontrolloivat kysymykset hyödyllisiksi lukuprosessissa, mutta eivät halunneet rajoittua vain niihin lukupiirissä. Olivia (A1.3) viittaa tähän esimerkissä 8:

(8) Olivia: It was boring later in lukupiiri because we did through those questions. Only those questions and answered and did not really talk. It was better when we discussed my own opinion too and not only answer from the book.

Olivia (A1.3) kritisoi, että lukupiiri oli pitkäveteinen silloin, kun siellä käytiin vain valmiit kysymykset läpi, vastattiin suoraan kirjasta eikä keskustelua omista näkemyksistä syntynyt. Vastaavista L2-lukijoiden kirjallisuuskeskustelun kokemuksista on raportoinut Kim (2004: 161-162). Luke (A1.3) ehdottaa opettajan tuomien kysymysten lisäksi osallistujien itsensä tekemiä täydentäviä kysymyksiä:

(9) Luke: Maybe the students could ask questions that are a little more abstract so... like "What do you think the character was planning?" or "What do you think the character thinks happened?" or... So something that is not concrete in the text that you just question-answer, repeat answer from the text directly. ---. Cause then you'd have to really think in Finnish and discuss something that is not concrete written there.

Luke toivoo käsiteltäväksi kysymyksiä, joiden avulla tekstin aukkoja voitaisiin täyttää tulkinnalla (ks. Vaarala 2009: 212), kuten mitä kirjan henkilö ehkä luuli tapahtuneen sen sijaan, että vain luetaan tekstistä suoria vastauksia. Toiminta, jossa osallistujat itse muodostavat kysymyksiä, kuten Luke ehdottaa esimerkissä 9, voi Urlaubin (2012: 301) havaintojen mukaan parantaa teoksen ymmärtämistä ja auttaa L2-oppijaa tuottamaan vahvempia tulkintoja. Tämä koskee myös aivan yksinkertaisiakin itse tuotettuja kysymyksiä (Eddy 2019: 54). Daniels (2002: 22-24) toteaa, että lukupiiriläisten täytyisi antaa tuoda mukaan omia keskustelunaiheitaan, koska näin he saavuttavat omistajuutta lukupiiristä ja hallinnoivat itse ajatteluaan ja keskustelua.

Kuten Uriah edellä (esimerkissä 7), myös Luke (esimerkissä 9) katsoi, että tällaisia tulkintakysymyksiä pohtiessa on ajateltavakin suomeksi. George tuo esiin tulkinnan yleisemmän merkityksen ja suhteen kieleen esimerkissä 10: 
(10) George: Because I think making interpretation of something, this case the book, will put you more with the story, with the characters and with what they lived and... Now you know for sure what is the feeling that Kaisu has in the morning or what happened in her head when she did something. When you have to think in Finnish.

Georgelle tulkinta merkitsi henkilöhahmojen tunteiden ja ajatusten ymmärtämistä, ja hän viittasi suomeksi ajattelemisen välttämättömyyteen tässä tulkintatoiminnassa. On hyvin tarkoituksenmukaista ilmaista omaa kokemusta kirjallisuudesta kohdekielellä (Christie 2019: 133), ja nämä lukupiiriläisten kokemukset tarpeesta ajatella suomeksi tukevat myös lukupiirin kielenopetuskäyttöä. Carrolin (2008: 93) havainnon mukaan kielenoppimista ei tapahtunut yhtä paljon, jos teosten käsittely kohdekielellä rajoittui tekstin sisällön selvittämiseen, mutta tulkinta tapahtui jollain muulla kuin kohdekielellä. Käytettäessä kirjallisuutta kielenopetuksessa kielellistä perspektiiviä ei voikaan asettaa etualalle, vaan on mentävä merkityksellinen kaunokirjallinen kokemus ja keskustelu edellä (Economou 2015: 113).

Toisinaan osallistujat saattoivat laajentaa keskustelua kysymällä omia kysymyksiä tai tuomalla keskusteluun uusia teemoja. Esimerkissä 11 Nelly keskeyttää sisältökysymysten läpikäynnin ja yrittää tuoda keskusteluun kritiikkinsä teoksen 2 juonenkäännettä kohtaan:

(11) [Nelly kritisoi kirjan ratkaisua:]

Nelly: Mutta minusta se on vähän hauskaa, että joka kodissa on jotain, mm, jotain metallista.

Isabella: Joo. ---. [Lukee ääneen seuraavan valmiin kysymyksen.]

[Kysyvät ja vastaavat, kunnes kysymykset loppuvat.]

Opettaja: No niin. Onko teillä loppu?

Nelly: Joo. Minusta se on vähän hauska, kun komisario ajatteli, että se voi olla pappi, murhaaja voi olla pappi, koska kirkossa on metallikynttilän...jalkoja. Ja se voi olla, aa, [katsoo kirjaa] murha-ase.

Opettaja: Joo.

Nelly: Mutta ajattelen, että joka kodissa on jotain metalli, iso metalli. [Nauraa.] Se voi olla myös murha-ase. [Nauraa.]

Opettaja: Joo. Totta.

Nelly: Se on vähän hauskaa logiikka.

Opettaja: Joo on vähän ehkä yksinkertainen logiikka, että joo metalli, joo, pappi, kirkko, okei...

Nelly: Ja kirkossa on. [Nauraa.] 
Nelly haluaa esittää kritiikkinsä, mutta keskustelukumppani Isabella ei tartu Nellyn avaukseen, vaan vie keskustelun heti takaisin valmiiden sisältökysymysten läpikäyntiin kysymällä seuraavan kysymyksen. Kun kysymysten läpikäynti on päättynyt, Nelly palaa asiaan ja avaa keskustelun vuorostaan opettajan kanssa. Nellyllä on selvä halu saada kertoa oma näkemyksensä kirjan ratkaisusta. Tulkitsevaa keskustelua tarvitaan, koska se on S2-lukijalle tärkeää oman kokemuksen ilmaisua. Aineistossani osallistujat toivoivat mahdollisuutta tulkitsevaan keskusteluun kielitaidon tasosta (A1.3-B1) riippumatta.

\subsection{Tulkinnan muodostaminen ja tukeminen}

Rosenblatt (1982: 268-629) on esittänyt, että lukijan asennoituminen tekstiin asettuu jatkumolle, jossa vaihtelevat tietoa hakeva (efferent) ja esteettinen lukeminen. Nämä asennoitumistavat voivat vaihdella samallakin lukijalla eri vahvuisina eri lukutilanteissa, mutta myös henkilöiden välillä on eroja. Samaan lukupiiriin osallistuneet Daniel (vahva A2) ja Hannah (A2) edustivat näitä kahta hyvin erilaista lukutapaa. Daniel etsi tulkintakysymyksiin selkeää vastausta teoksesta 3:

(12) Opettaja: ---. Mutta miksi hän näkee tällaista unta?

Daniel: Miksi? [Tutkii tekstiä.] Mä... Ei kirjoita miksi. [Indikoi hämmennystä.]

Opettaja: Joo, nyt sinun pitää itse miettiä, miksi.

Danielin etsii esimerkissä 12 suoraa vastausta miksi-kysymykseen kirjasta. Se ei kuitenkaan tarjoa sellaista vaan vastaaminen edellyttäisi oman tulkinnan muodostamista. Danielin oli vaikea oppia lukupiirissä keskustelemaan tulkinnoista mahdollisesti, koska tällainen keskustelu ei vastannut hänen lukutapaansa. Danielin lukutapa vastaa Rosenblattin (1982: 269) kuvaamaa tietoa hakevaa lukemista. Siinä lukija suhtautuu tekstiin tiedon lähteenä ja liikkuu faktatasolla. Yleensä tällaista lukutapaa käytetäänkin asiatekstien ja esimerkiksi käyttöohjeiden lukemiseen. Mutta toisin kuin tietoa hakevassa lukemisessa, lukupiirin lukutilanteessa ei ole esimerkiksi sisällön oppimisen tavoitetta tai muuta, mikä tekstistä pitäisi omaksua tietona tai ohjeena (ks. Rosenblatt 1982: 269, 274). Daniel ei ollut aiemmin harrastanut kaunokirjallisuuden lukemista, mutta korkeakoulutaustaisena oli varmasti harjaantunut tietoa hakevassa lukemisessa. Palaan tulkinnan haasteisiin alaluvussa 3.4.

Danielista poiketen Hannah pyrki aivan lukupiirin alusta alkaen tulkitsevaan keskusteluun, vaikka hän ei ollut vielä saavuttanut samaa kielitaidon tasoa kuin Daniel ja muut saman lukupiirin osallistujat. Esimerkissä 13 hän pyrkii laajentamaan keskustelua omaan tulkintaansa teoksen 3 katkelmasta. 
(13) [Hannah pohtii, miksi kirjan henkilö päätyy itsemurhaan. Tapahtumien kausaalisuhteita selvitetään sen vuoksi tekstin tasolla koko ryhmän kesken.]

Opettaja: Ymmärrätkö nyt paremmin?

Hannah: Joo, mutta miksi tappoi? Minä ymmärrän, mä ymmärrän, tämä selvä. Mutta kun mä lui[n] tämä sana: hän ei kestänyt vaan tappoi itse[nsä], [esittää kirjan lukemista painokkaasti henkäisten ja huudahtaen:] mitä tämä?!

Opettaja: Joo se on aika dramaattinen siinä.

Hannah tuo keskustelun kuluessa esiin, että hän ymmärtää kyllä, mitä kirjassa tapahtuu ja mitkä ovat kirjassa esitetyt syyt tapahtumiin, ja ilmaisee sen tässä katkelmassa myös suoraan: Minä ymmärrän, mä ymmärrän, tämä selvä. Sen sijaan hänen on vaikea henkilökohtaisesti hyväksyä näitä syitä, ja ne herättävät hänessä tunteita: mitä tämä?! Tästä hän yrittää myös keskustella ja luoda omaa tulkintaansa henkilöhahmon itsemurhaan johtaneista syistä. Hannahin suhtautuminen luettuun vastaa tässä tilanteessa Rosenblattin (1982: 269, 276) esteettistä lukemista, jossa painottuu elämyksellisyys, sillä lukija keskittyy tunteisiin, ajatuksiin ja kokemuksiin, joita lukeminen hänessä herättää.

Aluksi kyseisessä lukupiirissä muut eivät lähteneet tähän keskusteluun mukaan, joten Hannah ei saanut tukea pyrkimykselleen muodostaa keskustellen henkilökohtaista tulkintaa. Myöhemmin lukupiiriin liittyi kuitenkin George (B1), jolle Hannahin tulkitseva lähestymistapa sopi. Hannah kertoi, että oli harkinnut lukupiirin keskeyttämistä, koska koki, että muut keskustelivat niin eri tavalla. He selvittivät tekstin sanoja ja tapahtumia, mutta kun ne tulivat ymmärretyiksi, pohdintaa ei jatkettu. Cullerin mukaan (1997: 64) sen toteaminen, mistä tekstissä tällaisella konkreettisella tapahtumien tasolla on kyse, ei ole tulkintaa. Tässä mielessä Hannah oli lukupiirissään aluksi ainoa, jonka tavoite ei ollut vain ymmärtää sisältöjä vaan myös muodostaa tulkintaa niistä.

Tulkinnassa tärkeää on sen kertominen, miten siihen on päästy ja miten tekstin yksityiskohdat suhteutuvat tulkinnan muodostamiseen (Culler 1997: 63, 65), ja George ja Hannah toimivat juuri näin tulkintojaan perustellen. Perustelut ovat seuraavassa katkelmassa ilman kursiivia:

(14) [George ja Hannah keskustelevat, onko Rouva oikeasti sairas.]

George: Ei ole. Hän tekee... Se on teatteri. Se on hyvä... timing?

Opettaja: Ajoitus.

George: Ajoitus.

[kirjoittavat]

Hannah: Mutta hän jää sairaalassa. Erni sanoo [katsoo kirjaa]: "Ottivat hänet sairaalaan". Jos ei sairas, menee pois. 
George: Se on niin hyvä ajoitus, ei ole oikeasti sairas.

Hannah: Minä uskon Rouva sairas.

George: Hän ehkä... tämä... pää sairas [koputtaa päätänsä]. Ja miksi hän nauraa jos on sairas?

Hannah: Koska hän iloinen Kaisu kantaa hän... hänt...hänet.

[George puistelee päätään hymyillen.]

George on tulkinnut, että Rouva vain näyttelee sairasta ja käyttää tulkintansa perusteluna hyvää ajoitusta, jolla hän viittaa kirjan edellisessä luvussa olleeseen riitaan rahasta. Hannah taas vetoaa siihen, että Rouvan täytyy olla sairas, koska sairaalaan ei oteta terveitä. Vaarala (2009: 188) toteaa, että kaunokirjallisen tekstin lukemiselle on tyypillistä tekstissä edestakaisin liikkuminen ja aiempaan palaaminen eli rekursiivisuus, mutta tämä voi olla L2lukijoille haasteellisempaa kuin L1-lukijoille. Esimerkissä 14 George ja Hannah kuitenkin liikkuvat tekstissä rekursiivisesti edestakaisin ensin taaksepäin edelliseen lukuun, jossa oli riita ja johon George viittaa hyvän ajoituksen tulkinnallaan, ja siirtyvät sieltä tapahtumien loppuun eli sairaalaan jäämiseen. Sitten he taas palaavat tekstissä takaisinpäin Rouvan sairauskohtaukseen ja siihen, miten Kaisu kantoi häntä autoon. Tässä mielessä keskustelu muistuttaa rekursiivisuudessaan sitä, mitä Vaarala (2009: 190) pitää tavanomaisena L1-lukijoiden kirjallisuuskeskusteluille. L2-lukijat eivät hänen mukaansa poimi tekstistä yhtä laajalta alueelta perusteluja tulkinnoilleen kuin L1-lukijat. On kuitenkin huomattava, että Vaaralan tutkimuksessa ei käytetty selkotekstiä vaan yleiskielistä tekstiä, mikä todennäköisesti selittää eroa siinä, mikä on L2-lukijalle mahdollista.

Kaikki eivät kuitenkaan toimineet Hannahin ja Georgen tavoin aktiivisesti tulkiten. Silti tulkinnan muodostamista on mahdollista oppia toisella kielellä (Carter 1997: 155), ja lukupiireissä näin kävikin. Tämä edellytti opettajan aktiivista tukea. Esimerkissä 15 teoksessa 3 on tilanne, jossa henkilöhahmo Rouva hiipii yöllä salaa päähenkilö Kaisun huoneeseen ja ottaa Kaisun tavaroiden joukosta lakanan varastaakseen sen. Keskustelu alkoi tekstin kielellisiä merkityksiä selvittämällä, ja sen jälkeen päästiin esimerkissä käytävään keskusteluun. Tulkitsevat puheenvuorot, joissa täytetään tulkinnalla tekstin aukkoja (ks. Vaarala 2009: 212), on merkitty ilman kursiivia.

(15) Opettaja: Mutta miksi sitten Rouva tekee näin [yrittää varastaa lakanan]? Daniel: Hän haluaa herättää.

Beatrice: Joo.

Edwin: Joo.

Beatrice: Mm. Ehkä. 
Opettaja: Ei hän ehkä halua herättää, hän tekee sen salaa. Siellä sanotaan, että hän penkoo salaa Kaisun tavaroita.

Daniel: Joo.

Edwin: Ehkä hän haluaa lakana. Lakanoita.

[Hiljaisuus.]

Opettaja: Joo. Miksi hän haluaa Kaisun lakanoita?

Edwin: Joo, hän haluaa Kaisun lakanoita ehkä.

Daniel: [Tutkii kirjaa.] En mä tiiä, miksi hän haluaa Kaisun lakanoita. Mh.. Noh... [tutkii kirjaa, puistelee päätä].

[Hiljaisuus.]

Opettaja: Miksi hän menee Kaisun huoneeseen ja alkaa penkoa tavaroita ... ja ottaa...

Beatrice: Koska hän etsii jotain, mutta me emme tiedä mitä.

Edwin: Häiritsee, häiritsee häntä [Kaisua]...

Adam [huudahtaa]: Koska hän on paha!

Beatrice: Joo! Hän on paha! Totta kai!

Adam: Joo koska Kaisu nukkuu ja.

Edwin: Koska hän ei halua, että... Kaisu ... työ täällä paikalla...

Opettaja: Työskentelee.

Edwin: Joo työskentelee täällä paikassa.

Beatrice: Koska hän en... ei tykkää Kaisus... Kaisulta. Kaisusta.

Keskustelusta näkyy, että opettajan on kysyttävä monta kertaa miksi-kysymys. Tässä interrogatiivinen miksi-lausuma esiintyy hakukysymyksenä, jolla haetaan vastausta avoimeen kohtaan, mutta avointa kohtaa täyttävä hakukysymys voisi toki olla muunkin muotoinen kuin miksi (ISK § 734). Opettaja valitsee tässä tulkinnalla täytettävän aukon ja yrittää viedä keskustelua tulkitsevampaan suuntaan. Kramsch (2000: 223-224) on todennut, että opettajan kärsivällinen rohkaisu voi olla tarpeen tulkitsevan keskustelun luomiseksi. Esimerkin 15 keskustelijoista Edwin ja Beatrice ovat ennestään innokkaita kaunokirjallisuuden harrastajia L1kielellään, mutta hekin tarvitsevat tukea tulkintatoimintaan. Lisäksi opettajan on johdateltava keskustelijoita muistuttamalla: Ei hän ehkä halua herättää, hän tekee sen salaa. Mahdollisesti tällä kertaa rekursiivisuus ilmenee haasteena, kuten Vaaralan (2009: 190) tutkimuksen L2-lukijoilla. Ennen tähän keskusteluun siirtymistä käsiteltävän tekstinkohdan merkityksiä käsiteltiin tarkasti, esimerkiksi penkoa salaa merkityksestä keskusteltiin. Se, että Rouva toimii salaa ja haluaa varastaa, ei kuitenkaan tule aluksi rekursiivisesti osaksi tulkintaa, vaan Daniel arvelee, että Rouva haluaa herättää Kaisun. Hän ei siis näin tuo tekstistä edeltävää kontekstia tulkintansa osaksi ilman tukea. 
Alaluvussa 2.2 määrittelin tulkinnan perusedellytyksiksi havainnon ja ymmärryksen. Kun tekstin merkityksiä on riittävästi sekä havaittu että ymmärretty (tekstin lukeminen ja tekstin merkityksiä selvittävä keskustelu), ja opettaja onnistuu johdattelemaan osallistujia sopivasti (sinnikäs kysyminen hieman eri tavoilla ja rekursiivinen perustelu: siellä sanotaan, että hän penkoo salaa), tulkintoja alkaa tulla. Tulkinnat näkyvät esimerkin 15 lopussa kursivoitujen vuorojen runsautena. Tässä vaiheessa myös opettajan ohjaava ote jää pois ja lukupiiriläiset keskustelevat keskenään.

Kim (2004: 155) toteaa, että hänen lukupiiritutkimuksessaan kielenoppijat saattoivat joskus siirtyä kirjaimellisesta ymmärryksestä tulkintoihin. Omassakaan tutkimuksessani itsenäinen tulkintaan pyrkiminen ei ollut säännönmukaista. Useimmiten tutkimukseni lukupiirien osallistujat selvittävät tekstin kielen semanttista sanojen, rakenteiden ja ilmausten tasoa. Tätä myös Vaarala (2009: 148-149), Kim (2004: 151-152) ja Economou (2015: 106) pitävät L2-kirjallisuuskeskustelujen yhtenä ominaisuutena. Samoin S2-lukijat selvittävät tietoa hakevaa lukemistapaa käyttäen tekstin faktuaalista sisältöä eli henkilöiden, tapahtumien ja kausaalisuhteiden tasoa: kuka, mitä, missä ja niin edelleen (ks. Kim 2004: 162; Langer 1990: 248-249; Diamantiki 2016: 63; Rosenblatt 1982: 269). Näiden ilmaisemiseen on myös mahdollista ottaa kielellistä tukea kirjasta, josta voi löytyä jopa oikea vastaus sellaisenaan. Osalle S2-lukijoista tämä voi olla lukemisen antina riittävää ja hyvää lukupiiritoimintaa, mutta tämä keskustelu oli tärkeä usein myös niille, jotka halusivat lisäksi tulkita.

Kaunokirjallinen teksti sisältää myös syvempiä, piilotettuja merkityksiä (Kim 2004: 155), tulkinnalla täytettäviä aukkoja (Vaarala 2009: 212). Niitä tekstissä ei eksaktisti ilmaista, vaan ne on pääteltävä eikä teksti ei anna tähän suoraa kielellistä tukea. Tästä syystä siirtymä ymmärryksen tasolta uusien merkitysten ja tulkinnan luomiseen on kielenoppijalle yleensä haastava (Diamantiki 2016: 62). Carroli (2008: 75) toteaa, että kaunokirjallisen tekstin yksinomainen kirjaimellisen pintatason luenta estää L2-lukijaa näkemästä tekstin varsinaisia merkityksiä toisin kuin esteettinen lukeminen. Selkomukautetunkaan kaunokirjallisuuden pelkkä semanttisen ja faktuaalisen sisällön selvittäminen ei riitä teoksen piilotettujen merkitysten ymmärtämiseen, koska ne ovat vain tulkinnalla tavoitettavissa. Ei olekaan yllättävää, että monet toivoivat lukupiiriltä tulkitsevaa keskustelua tuekseen. Joskus on esitetty, että kirjallisuuden kielen yksinkertaistaminen L2-lukijan ymmärryksen lisäämiseksi riisuisi tekstiltä kaunokirjallista arvoa ja syvyyttä, ja vain yleiskielinen kirjallisuus mahdollistaisi kompleksisen tulkinnan (Carroli 2008: 11-12). Tutkimukseni S2-lukijoiden toiminnan valossa näin ei ole. Lukijan tehtävä on ideoida ja rakentaa merkitys sille kirjallisuuden todellisuudelle, jota ei kerrota suoraan (Gonçalves Matos 2012: 75), ja tämä taiteellinen dynamiikkaa koskee myös tutkimukseni selkoteoksia. Se näkyy erilaisina tulkintoina esimerkeissä 14 ja 15 ja samoin 
Uriahin kokemuksessa eri tulkintavaihtoehdoista esimerkissä 7. Myös esimerkiksi George kertoi pitävänsä lukupiirin kirjasta, koska siinä on paljon tunteita, joita ei selitetä suoraan, vaan niitä täytyy tulkita.

\subsection{Tulkinnan haasteet}

Tulkinnan tukemisen kannalta on olennaista tarkastella, millaisia haasteita S2-lukija voi kohdata siinä. On ensinnäkin mahdollista, ettei tulkintaa vielä osata tehdä. Edellä olen käsitellyt Danielin kohtaamia haasteita tässä (alaluku 3.3), ja Claridgen (2011: 190) tutkimuksessa tietoa hakeva lukutapa olikin yhteydessä kokemattomuuteen kaunokirjallisuuden lukemisessa L1-kielellä. Osalla lukijoista ei myöskään ehkä ole vielä tulkinnan edellytyksiä, koska tekstistä ei vielä kielellisesti havaita tai ymmärretä asioita, joiden pohjalta tulkinnan voisi tehdä, ja juuri havainto ja ymmärrys olivat tulkinnan määritelmälliset edellytykset (alaluku 2.2). Kaikkea ei toki tarvitse ymmärtää voidakseen tulkita, mutta lukupiireissä tämä teosten kielellinen haaste näkyi siten, että niissä käytiin paljon tekstin semanttiseen ja faktuaaliseen tasoon kohdistuvaa, ymmärtämistä tukevaa keskustelua.

Monen S2-lukijan ymmärrystä tukivat lukupiirin kysymykset, jotka ohjasivat havaitsemaan juonen kannalta keskeisiä asioita, mutta ne saattoivat myös suunnata keskustelun kulkua. Ymmärrystä kontrolloivat kysymykset voivat ohjata lukemaan tietoa hakevasti (Rosenblatt 1982: 274; Eddy 2019: 50). Todennäköisesti ne voivat siten ohjata lukupiirin keskusteluakin sivuuttamaan esteettisen näkökulman, mikäli keskustelussa rajoitutaan vain vastaamaan näihin kysymyksiin, mihin Olivia ja Luke viittasivat esimerkeissä 10 ja 11 . Claridge (2011:148) taas havaitsi, että tietoa hakevan lukutavan valinta voi olla myös L2-lukijan keino suojautua pettymykseltä, jonka hän kohtaisi epäonnistuessaan lukunautinnon ja esteettisen lukutavan tavoittelussa toisella kielellään. Toisaalta tulkinnan poissaoloa voi L2-lukijan kannalta selittää myös se, ettei hän ole varma, onko tekstissä jonkin aukko, jonka voisi tulkinnalla täyttää, vai eikö hän osaa jotakin tarvittavaa kielen tason asiaa tai ymmärrä kokonaisuutta (Vaarala 2009: 212). Näihin ongelmiin auttavat ryhmän tuki ja vuorovaikutus (ks. mt. 206, 212) ja myös opettajan tuki.

Kielitaidon tasolla tiedostettiin olevan merkitystä tulkinnan muodostamisessa. Olivia kertoo esimerkissä 16, etteivät hänen keskustelukumppaninsa aina hyväksyneet hänen tulkintojaan kielitaitoerojen (A1.3) vuoksi: 
(16) Mervi: In this class [lukupiiri] the book is discussed. Does that help you?

Olivia: Yes, but sometimes it depends on the group you are with. Because some of my class mate they are more in advance, so for me, l've started from zero, for me sometimes they might felt that my answer is not this what they want and sometimes I felt that their answer is not what I want.

Toisaalta Olivia itsekään ei aina halunnut hyväksyä kielen kehityksessään pidemmälle ehtineiden keskustelukumppanien tulkintoja. Tässä tapauksessa kielen hallinta vaikutti tulkintoihin siten, etteivät ne tulleet hyväksytyksi puolin ja toisin. Vaaralan (2009: 155) mukaan L2-lukijoiden päättelyketju voi joskus täysin poiketa L1-lukijoiden päättelyketjusta ja siten tulkintakin on aivan erilainen. On mahdollista, että sama ilmiö voi koskea myös eri kielitaidon tasoilla olevien tulkintaa.

Lisäksi haastatteluissa tuotiin ilmi toisen kielen tuottamisen haasteita. Joidenkin oli vaikea saada ilmaistua asioita sanallisesti silloin, kun niitä ei voinut lukea kirjasta suoraan. Isabella (A1.3) kertoi:

(17) Isabella: Mutta minä ymmärrän [kirjaa], mutta se on vaikea puhu... silittää [selittää]. Se [keskustelu] menee... nopea.

Lukupiirin video- ja ääniteaineistosta tuli ilmi, että Isabella ymmärsi lukemansa sisällön tasolla. Hän esimerkiksi löysi kirjasta nopeasti kirjasta sanat ja muodot, joita muut tarvitsivat keskustelussa. Keskustelun nopeus oli hänestä ongelmallista, kuten hän esimerkissä 17 ilmaisee. Lopputuotteen, produktiivisen kohdekielisen tuotoksen (tässä tulkinnan) puuttuminen ei välttämättä kerrokaan puuttuvista prosesseista (Swain ym. 2015: 68) eli tässä tulkintakyvystä. On mahdollista, että Isabella osaa tulkita kaunokirjallisuutta, mutta ei kykene vielä ilmaisemaan itseään toisella kielellään riittävästi: se on vaikea puhu... s[e]littää. Vaarala (2009: 162, 213) havaitsi tutkimuksessaan, että L2-lukijat eivät aina näyttäneet muodostavan tulkintaa, koska heiltä mahdollisesti puuttui siinä tarvittavaa abstraktia sanastoa. Isabellalla saattoi olla ajatuksia, mutta ne jäivät kielitaitotason ulottumattomiin, kun muut keskustelivat sujuvammin ja nopeammin. Jotkut A1.3-tasoiset toivoivat, että saisivat keskustella lukupiirissä muiden samantasoisten kanssa.

Huomiota herättää, että vaikka tulkintakeskustelua toivottiin, mutta sitä ei kovin usein käyty itsenäisesti. Tuki mahdollistaakin suorituksen, johon oppija ei vielä pysty itsenäisesti, mutta jonka hän voi jo saavuttaa tuettuna (Ohta 2000: 86; Vygotsky 1978). Kokemattomuus L1-lukemisessa näyttäisi hankaloittavan esteettistä lukutapaa L2-kielessä (Claridge 2011: 190), mutta silti kokeneisuus L1-lukijana ei automaattisesti näytä tuottavan sitä S2lukemiseen, sillä tutkimuksessani 15 osallistujaa harrasti ennestään kaunokirjallisuutta 
muilla osaamillaan kielillä. Heistä kaikki eivät alkaneet välittömästi tuottaa tulkintoja ja keskustella niistä, vaikka monet ilmaisivat kaipaavansa juuri sitä. Syy voi piillä tulkintaprosessien moninaisuudessa: Tulkinta edellyttää aluksi tekstin ymmärtämistä. Sitten on tuotettava teoksen piilotettujen merkitysten pohjalta oma tulkinta, ja koska piilotetut merkitykset voivat olla teoksessa laajalla alueella, lukeminen vaatii rekursiivisuutta. Muodostunutta tulkintaa tulee vielä lukupiirin tapauksessa ilmaista toisella kielellä. Lukija voi näin kohdata monenlaisia kielellisiä haasteita samanaikaisesti sekä reseptiivisten että produktiivisten taitojen alueella. Voikin olla, että näistä syistä tulkinnan malleja ei ehkä aluksi siirretä (transfer) (ks. Wiggins \& McTighe 2005: 40) muista kielistä, joilla tulkintaa on mahdollisesti tehty aiemmin. On nimittäin mahdollista, että niiden, joilla on korkeampi kielitaitotaso, on helpompaa siirtää lukemisen taitojaan toiseen kieleen (Aebersold \& Field 1997: 22, 25, 34), ja B1-tasoiset tulkitsivatkin tekstiä oma-aloitteisesti useammin kuin muut. Edellä Isabella ei mahdollisesti vielä onnistunut siirrossa ehkä juuri kielitaidon tasonsa (A1.3) vuoksi. Siirto (transfer) voi koskea niin tietoja kuin taitoja esimerkiksi lukemisessa, ja se merkitsee niiden tuomista uuteen kontekstiin. Joskus siirto voi kuitenkin epäonnistua jopa parhaiten tiedot ja taidot yhdellä alueella hallitsevilta. (Wiggins \& McTighe 2005: 40-42.)

Eräät osallistujat viittasivat kokemuksenaan (esimerkit 7, 9, 10) siihen, että juuri tulkintatoiminnassa on ajateltava suomeksi. Tähän voikin perustua niin lukupiirin voima kielenopetuksen osana (ks. alaluku 3.2) kuin sekin, että tulkintoja toivottiin, mutta ei aina muodostettu ilman tukea. Kusanagi (2015: 235) on todennut lukupiireistä, että koska juuri kieli välittää kerrontaa, kielenoppijat tarvitsevat tukea toimiessaan kohdekielellään. Lukupiirin opettajan tulisi tukea lukupiirin osallistujien toimintaa kirjan parissa ja toistensa kanssa tuon toiminnan mahdollistajana (facilitator) esimerkiksi herättämällä tunteita ja ajatuksia ja auttamalla niiden ilmaisemisessa (Kim 2004: 146; Daniels 2002: 22-24). S2-lukupiirissä tulkinnan muodostamisen ei tarvitse olla kaikkien tavoite, mutta se oli monen toive. Parhaimmillaan lukupiiri toimijoineen ja selkoteoksineen muodosti tuen, joka auttoi ylittämään tulkinnan esteitä ja saavuttamaan sellaista keskustelua, jota monet ilmaisivat toivovansa lukupiiriin enemmän.

\section{Lopuksi}

Olen tässä artikkelissa selvittänyt S2-lukijan tulkinnan muodostamista lukupiirissä, mitä haasteita siinä on ja millaista tukea siinä tarvitaan. Tulkinnan muodostamisen pohjana ovat havainto ja ymmärrys. S2-lukijan kaunokirjallisuuskeskustelu olikin usein kielen semanttiseen ja sisällön faktuaaliseen tasoon kohdistuvaa. Tähän ovat aiemmin viitanneet esimerkiksi 
Kim (2004) ja Vaarala (2009). Kimillä se ei kuitenkaan tule yhtä korostuneesti esiin, ja Vaaralan havainto liittyy pääasiassa sanojen merkitysten keskeisyyteen kirjallisuuskeskusteluissa. Kaunokirjallisuudessa on kuitenkin piilotettuja merkityksiä, joihin pääsee käsiksi vain tulkinnan kautta. Produktiivinen oman tulkinnan tuottaminen ja siitä keskustelu oli monille haaste, vaikka he olisivat olleet kokeneita lukijoita muilla osaamillaan kielillä. Haasteellisuus liittyi usein kielitaitoon ja tulkinnan taidon siirtämiseen kielestä toiseen, mutta joskus myös itse tulkintataitoon. Tulkintojen tuottamisen ei tarvitse olla lukupiirien kaikkia S2-lukijoita koskeva yleistavoite, mutta monet ilmaisivat halua tulkita ja pettymystä, jos näin ei tehty. Ilman tukea tulkitsevaa keskustelua kuitenkin syntyi hyvin vähän, vaikka selkoteokset sinänsä mahdollistivat monenlaiset kaunokirjalliset tulkinnat.

Lukupiireissä käytettiin opettajan tuomia valmiita kysymyksiä. Osa koki kysymykset hyvin tarpeellisena sisällönymmärtämisen strategisena tukena, jotkut taas kokivat ne rajoittavina jopa siinä määrin, että erosivat lukupiiristä. Aiheesta on kirjoitettu jo aiemminkin tutkimuskirjallisuudessa (esim. Claridge 2011; Christie 2019), mutta oma tutkimukseni toi sille empiiristä vahvistusta. Kysymyksiä oli kahta lajia: sisällönymmärtämistä kontrolloivia kysymyksiä ja oman tulkinnan muodostamista edellyttäviä kysymyksiä. Kritiikki kohdistui erityisesti sisällönymmärtämiskysymyksiin. Monet toivoivat enemmän jälkimmäisiä, tulkintakysymyksiä, ja että lukupiiriläiset voisivat myös itse esittää kysymyksiä. Kysymykset toisaalta loivat keskustelua mutta toisaalta myös rajoittivat sitä, jos opettaja ei aktiivisesti ohjannut keskustelua kohti osallistujien omia näkemyksiä. Monien halu saada muodostaa oma tulkinta ja kertoa se oli ilmeinen, eikä se ollut riippuvainen kielitaidon tasosta. Nekään, joiden produktiivinen kielitaito ei vielä aivan yltänyt tulkitsevaan keskusteluun, eivät yleensä halunneet ohittaa sitä. Tämä on hyvä huomioida lukupiiritoimintaa suunnitellessa.

Lukupiiritoimintaa on aiemmin tarkasteltu melko vähän sosiokulttuurisen tuen näkökulmasta. Tuen avulla vielä itsenäisen suoriutumisen ulkopuolella oleva tulkintatoiminta oli mahdollista jo saavuttaa. Tuen näkeminen monimuotoisena ja laajasti muunakin kuin pedagogisena menetelmävalintana oli tässä lähtökohtana. Tällaisena tukea ovat aiemmin käsitelleet muiden muassa Suni (2008) ja Swain ym. (2015). Lukupiirien tarjoama tuki oli monipuolista. Monet kokivat sisältökysymysten ja lukupiirin vertaistuen auttaneen ymmärtämään kirjan sisältöjä paremmin. Tuki ilmeni myös opettajan antamina tulkintavihjeinä, kun opettaja ohjasi tekemään havaintoja tekstistä ja ohjasi osallistujia muodostamaan ja kertomaan oman tulkintansa. Tärkeä tuen muoto oli lukupiirin teosten selkokieli, joka mahdollisti kaunokirjallisen lukemisen jo osallistujien senhetkisessä kielitaidon vaiheessa. S2-lukijat kokivat selkoteosten parissa lukunautintoa, mikä taas oli ratkaisevan tärkeää lukemisen jatkumiselle. Selkokielen merkitystä lukunautinnolle ja kaunokirjallisuuden saavutettavuudelle ovat aiemmin 
korostaneet esimerkiksi Leskelä (2019) ja Claridge (2011), ja oma tutkimukseni toi tähän empiiristä vahvistusta S2-lukijoiden osalta. Myös lukupiirin yhteisöllinen toimintamuoto näyttäytyi olennaisena. Lukupiiri on S2-lukijalle ympäristö, jossa voi päästä keskustelemaan suomeksi kirjasta ja tulkinnoista. Lukupiiri on myös yhteisöllinen keino tukea S2-lukijan suomeksi lukemista, sisällönymmärtämistä tai oman, suomenkielisen tulkinnan muodostamista riippuen kunkin lukijan toiveista ja tavoitteista.

Koska S2-lukijoiden ja lukupiirien tutkimusta on toistaiseksi vähän, jatkotutkimuksissa voisi tarkastella esimerkiksi kirjallisuuskeskustelujen kielen ja vuorovaikutuksen tasoa yksityiskohtaisemmin. Samoin selkoteosten tarkempi tutkimus sekä kielen- että kirjallisuudentutkimuksen keinoin olisi tärkeää.

\section{Kirjallisuus}

Aebersold, J. A. \& M. L. Field 1997. From reader to reading teacher: issues and strategies for second language classrooms. Cambridge: Cambridge University Press.

Brewer, J. D. 2000. Ethnography. Buckingham: Open University Press.

Carroli, P. 2008. Literature in second language education. Enhancing the role of texts in learning. London: Continuum International Publishing Group.

Carter, R. 1997. Investigating English discourse: language, literacy and literature. Oxon: Routledge.

Christie, C. 2019. Literature and the target language. Teoksessa F. Diamantidaki (toim.) Teaching literature in modern foreign languages. London: Bloomsbury Academic, 113137.

Claridge, G. M. H. 2011. What makes a good graded reader: engaging with graded readers in the context of extensive reading in $L 2$. Wellington: Victoria University. http://hdl.handle.net/10063/1749

Culler, J. D. 1997. Literary theory: a very short introduction. Oxford: Oxford University Press.

Daniels, H. 2002. Literature circles. Voice and choice in book clubs and reading groups. Portland: Stenhouse Publishers.

Davis, J. N. 1992. Reading literature in the foreign language: the comprehension/ response connection. The French Review, 65, 359-370. https://www-jstor-org.ezproxy.jyu.fi/stable/395098

Day, R., \& J. Bamford 1998. Extensive reading in the second language. Cambridge: Cambridge University Press.

Diamantiki, F. 2016. Using literature in the key stage 3 modern foreign languages classroom. Teoksessa C. Christie \& C. Conlon (toim.) Success stories from secondary foreign 
languages classrooms. Models from London school partnerships with universities, London: UCL Institute of Education Press, 56-77.

Economou, C. 2015. Reading fiction in a second-language classroom. Education Inquiry, 6 (1), 99-118. https://doi.org/10.3402/edui.v6.23991

Eddy, J. 2019. Literature and drama for transfer. Teoksessa F. Diamantidaki (toim.) Teaching literature in modern foreign languages. London: Bloomsbury Academic, 45-62.

Emerson, R. M., R. I. Fretz \& L. L. Shaw 2011. Writing ethnographic fieldnotes. Second edition. Chicago: The University of Chicago Press.

Gibbons, P. 2003. Mediating language learning: teacher interactions with ESL students in a content-based classroom. TESOL Quarterly, 37, 247-274. https://www-jstororg.ezproxy.jyu.fi/stable/3588504

Gonçalves Matos, A. 2012. Literary texts and intercultural learning. Exploring new directions. Bern: Peter Lang.

ISK = Auli Hakulinen, Maria Vilkuna, Riitta Korhonen, Vesa Koivisto, Tarja Riitta Heinonen ja Irja Alho 2004. Iso suomen kielioppi. Helsinki: Suomalaisen Kirjallisuuden Seura.

Kastari, M. 2019. Aikuisten S2-oppijoiden kielenoppimisen kokemuksia selkomukautetun kaunokirjallisuuden parissa. Puhe ja kieli, 39 (4), 345-365.

Kim, M. 2004. Literature discussions in adult L2 learning. Language and Education, 18, 145166.

Kramsch, C. 2000. Social discursive constructions of self in L2 learning. Teoksessa J. P. Lantolf (toim.) Sociocultural theory and second language learning. Oxford: Oxford University Press, 200-229.

Kusanagi, Y. 2015: Literary reading circles and short essay activities for English learning among medical students. Teoksessa M. Teranishi, Y. Saito \& K. Wales. (toim.) Literature and language learning in the EFL classroom. Hampshire: Palgrave Macmillan, 233247.

Langer, J. A. 1990. The process of understanding: reading for literary and informative purposes. Research in the Teaching of English, 24 (3), 229-261. https://www.jstor.org/stable/40171165

Lehtonen, T. 2015. Pedagoginen perusta kielenoppimisessa. Teoksessa Y. Lappalainen, M. Poikolainen \& H. Trapp (toim.) Tila haltuun! Suositukset virtuaalisen suomen opiskelun toteuttamiseen. Turun yliopiston Brahea-keskuksen julkaisuja 6, 20-37.

http://hdl.handle.net/10138/156221

Leskelä, L. 2019. Selkokieli. Saavutettavan kielen opas. Helsinki: Kehitysvammaliitto ry. Marttila, A. 2014. Tutkijan positiot etnografisessa tutkimuksessa. Teoksessa P. Hämeenaho. \& E. Koskinen-Koivisto (toim.) Moniulotteinen etnografia. Helsinki: Ethnos, 362-392. 
Nissi, K. 2014. Etnografisia reflektioita sairaanhoidon kentältä. Teoksessa P. Hämeenaho. \& E. Koskinen-Koivisto (toim.) Moniulotteinen etnografia. Helsinki: Ethnos ry, 333-361.

Ohta, A. M. 2000. Rethinking interaction in SLA: developmentally appropriate assistance in the zone of proximal development and the acquisition of L2 grammar. Teoksessa J. P. Lantolf (toim.) Sociocultural theory and second language learning. Oxford: Oxford University Press, 85-125.

Papunetin kuvapankki. Papunet. https://papunet.net/materiaalia/kuvapankki [luettu 20.2.2020].

Rosenblatt, L. M. 1982. The literary transaction: evocation and response. Theory Into Practice, 21, 268-277. https://www-jstor-org.ezproxy.jyu.fi/stable/1476352

Rosenblatt, L. M. 1986. The aesthetic transaction. The Journal of Aesthetic Education, 20, 122-128. https://www-jstor-org.ezproxy.jyu.fi/stable/3332615

Sheehan, M. D. 2015. Increasing motivation and building bridges to content with graded readers. Teoksessa M. Teranishi, Y. Saito \& K. Wales (toim.) Literature and language learning in the EFL classroom. Hampshire: Palgrave Macmillan, 294-314.

Suni, M. 2008. Toista kieltä vuorovaikutuksessa. Kielellisten resurssien jakaminen toisen kielen omaksumisen alkuvaiheessa. Jyväskylä Studies in Humanities 94. Jyväskylä: Jyväskylän yliopisto. http://urn.fi/URN:ISBN:978-951-39-3209-1

Swain, M., P. Kinnear \& L. Steinman 2015. Sociocultural theory in second language education. An introduction through narratives. 2nd Edition. Bristol: Multilingual Matters.

Urlaub, P. 2012. Reading strategies and literature instruction: teaching learners togenerate questions to foster literary reading in the second language. System, 40, 296-304. https://doi.org/10.1016/j.system.2012.05.002

Vaarala, H. 2009. Oudosta omaksi. Miten suomenoppijat keskustelevat nykynovellista? Jyväskylä Studies in Humanities 129. Jyväskylä: Jyväskylän yliopisto. http://urn.fi/URN:ISBN:978-951-39-3773-7

Vygotsky, L. 1978. Mind in society: the development of higher psychological processes. Cambridge: Harvard University Press.

Weber, H. 1996. Gardeners in the DaF-classroom: poems and stories in intercultural learning. Teoksessa L. Bredella \& W. Delanoy (toim.) Challenges of literary texts in the foreign language classroom. Tübingen: Gunter Narr, 233-247.

Wiggins, G. \& J. McTighe 2005. Understanding by design. Expanded 2nd edition. Alexandria: Association for Supervision and Curriculum Development.

Yhteiskuntatieteellinen tietoarkisto 2017. Aineistonhallinnan käsikirja. Tampere: Tampereen yliopisto. https://www.fsd.uta.fi/aineistonhallinta/fi/kvalitatiivisen-datan-kasittely.html\#litterointi [luettu 15.1.2020]. 